$1-19-2021$

\title{
The Right to Seek Asylum in Canada (During a Global Pandemic)
}

\author{
Elise Mercier \\ Centre for Refugee Studies, York University \\ Sean Rehaag \\ Osgoode Hall Law School of York University
}

Follow this and additional works at: https://digitalcommons.osgoode.yorku.ca/ohlj

Part of the Law Commons

\section{Article}

\section{Citation Information}

Mercier, Elise and Rehaag, Sean. "The Right to Seek Asylum in Canada (During a Global Pandemic)." Osgoode Hall Law Journal 57.3 (2021) : 705-738.

https://digitalcommons.osgoode.yorku.ca/ohlj/vol57/iss3/7

This Article is brought to you for free and open access by the Journals at Osgoode Digital Commons. It has been accepted for inclusion in Osgoode Hall Law Journal by an authorized editor of Osgoode Digital Commons. 


\title{
The Right to Seek Asylum in Canada (During a Global Pandemic)
}

\author{
Abstract \\ This article analyzes the effect that the Canadian Government's use of emergency powers during the \\ COVID-19 global pandemic has had on the right to seek asylum in Canada. The article suggests that that \\ the federal government has taken advantage of a public health crisis to make a contentious political \\ problem-the entry of asylum seekers between land ports of entry (such as at Roxham Road)-go away. It \\ details how the Quarantine Act and various Orders in Council have been used to temporarily extend the \\ Safe Third Country Agreement between Canada and the United States (STCA) across the entire length of \\ the Canada-US border. It then details how this de facto extension of the STCA, which previously applied \\ only at official land ports of entry, violates international refugee law and overviews several ways in which \\ the global pandemic has made the United States even less "safe" for refugees. The article concludes by \\ urging the federal government to champion asylum seekers' rights by suspending the STCA and by \\ recognizing that crossing the border to seek asylum is amongst the most "essential" forms of \\ international travel that there is.
}




\title{
The Right to Seek Asylum in Canada (During a Global Pandemic)*
}

\author{
ELISE MERCIER ${ }^{+} \&$ SEAN REHAAG ${ }^{\ddagger}$
}

This article analyzes the effect that the Canadian Government's use of emergency powers during the COVID-19 global pandemic has had on the right to seek asylum in Canada. The article suggests that that the federal government has taken advantage of a public health crisis to make a contentious political problem -the entry of asylum seekers between land ports of entry (such as at Roxham Road) - go away. It details how the Quarantine Act and various Orders in Council have been used to temporarily extend the Safe Third Country Agreement between Canada and the United States (STCA) across the entire length of the Canada-US border. It then details how this de facto extension of the STCA, which previously applied only at official land ports of entry, violates international refugee law and overviews several ways in which the global pandemic has made the United States even less "safe" for refugees. The article concludes by urging the federal government to champion asylum seekers' rights by suspending the STCA and by recognizing that crossing the border to seek asylum is amongst the most "essential" forms of international travel that there is.

The authors are grateful for funding from York University's Research in the Time of COVID 19 program. They also appreciate research assistance provided by Nika Arbabzadeh Broujen, Tiffany Dang, Emma De Paoli, Genevieve Giesbrecht, Janet Song, Alexander Toope, Virginia Duarte Walsh, and Rachel Zaurov. They also thank the Osgoode Public Interest Requirement program for facilitating access to research assistance.

$+\quad$ Associate Lawyer, North Star Immigration Law \& Research Lawyer, Centre for Refugee Studies, York University.

‡ Director, Centre for Refugee Studies \& Associate Professor, Osgoode Hall Law School, York University. 


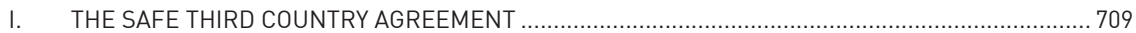

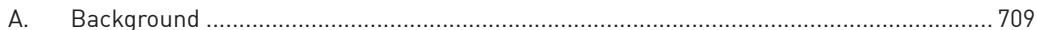

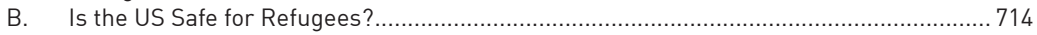

C. How Should the "Surge" in Entries Between POEs Be Addressed?............................... 717

II. THE DE FACTO EXTENSION OF THE STCA ACROSS THE ENTIRE LAND BORDER ...................... 719

A. Orders in Council and Altered Regulations ......................................................... 720

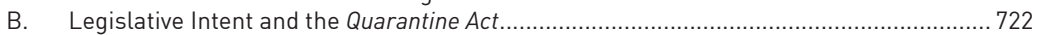

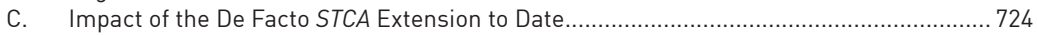

III. SOME OF THE BIGGEST PROBLEMS WITH THE DE FACTO EXTENSION OF THE STCA ................ 725

A. Do the Measures Penalize Asylum Seekers for Their Method of Entry? ........................ 726

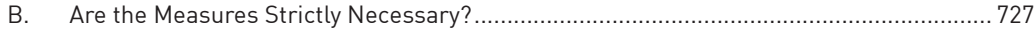

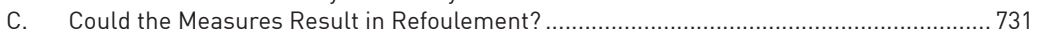

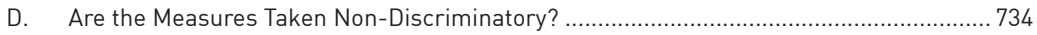

IS CROSSING A BORDER to seek refugee protection "essential travel”? To refugee advocates, it is obvious that fleeing human rights abuses is "essential." The Canadian government, however, appears to disagree. Soon after the COVID-19 virus was declared a "global pandemic" ${ }^{1}$ they deemed the travel of truck drivers, agricultural workers, and returning snowbirds as essential, ${ }^{2}$ but not that of asylum seekers. ${ }^{3}$

Prime Minister Justin Trudeau announced the use of executive powers under the Quarantine Act to turn away refugee claimants attempting to enter

1. World Health Organization, "Statement on the second meeting of the International Health Regulations (2005) Emergency Committee regarding the outbreak of novel coronavirus (2019-nCoV)" (30 January 2020), online: <www.who.int/news-room/detail/30-01-2020statement-on-the-second-meeting-of-the-international-health-regulations-(2005)-emergency -committee-regarding-the-outbreak-of-novel-coronavirus-(2019-ncov)> [perma.ccl HQR4-8SP6]; Jamie Ducharme, "World Health Organization Declares COVID-19 a 'Pandemic.' Here's What That Means," Time Magazine (11 March 2020), online: <time. com/5791661/who-coronavirus-pandemic-declaration> [perma.cc/JJ8S-GEX7].

2. Canada, Minimizing the Risk of Exposure to COVID-19 in Canada Order (Prohibition of Entry into Canada from the United States), (Order in Council), PC 2020-0161 (20 March 2020), s 3, online: <orders-in-council.canada.ca/attachment.php?attach=38958\&lang=en> [perma. cc/TA85-9LL4] [OIC, 2020-0161]; Public Safety Canada, "Guidance on Essential Services and Functions in Canada During the COVID-19 Pandemic" (9 April 2020), online: <www. publicsafety.gc.ca/cnt/ntnl-scrt/crtcl-nfrstrctr/esf-sfe-en.aspx> [perma.cc/BG4R-39HA].

3. Canada, Minimizing the Risk of Exposure to COVID-19 in Canada Order (Prohibition of Entry into Canada from the United States), (Order in Council), PC 2020-0263 (20 April 2020), s 5, online: <orders-in-council.canada.ca/attachment.php?attach=39170\&lang=en> [perma. cc/2YM6-LA3A] [OIC, 2020-0263]. 
the country from the United States in late March $2020 .{ }^{4}$ The Order in Council implementing these changes indicated that there were "no reasonable alternatives to prevent the introduction or spread of" COVID-19 in Canada. Although some restrictions were lifted in late April, most asylum seekers continue to be barred from entering the country. ${ }^{6}$ Refugee advocates have called this policy "arbitrary and unjustifiable." 7 We agree.

The government has given no timeline for lifting these measures. It is not clear what alternative measures were considered. Nor has the government explained why it did not implement measures recommended by the United Nations High Commissioner for Refugees (UNHCR) to respect asylum seekers' rights while protecting public health. These recommendations included, amongst others, either "continu[ing] asylum procedures in order to prevent backlogs" and implementing a series of adaptations to prevent COVID-19 transmission and ensure procedural fairness (such as using additional or alternative facilities with sufficient spacing or adopting remote interviewing modalities as alternatives to face-to-face interviewing) or implementing "an explicit exemption for asylum seekers" where "entry bans or border closures are implemented," combined with medical screenings and quarantine. ${ }^{8}$

The use of executive powers to make sweeping changes to refugee admission policies, without public consultation and parliamentary debate, is troubling and unprecedented. These changes are particularly disturbing given the concerns raised in recent litigation about the Safe Third Country Agreement (STCA), which is an international agreement between Canada and the United States. The STCA permits Canada to turn some asylum seekers back at the Canada-US border

4. Kathleen Harris, "Canada to turn back asylum seekers, close border at midnight to stop spread of COVID-19” CBC News (20 March 2020), online: <www.cbc.ca/news/politics/ trudeau-covid19-coronavirus-medical-equipment-1.5504149> [perma.cc/4YBY-EUDZ].

5. Canada, Minimizing the Risk of Exposure to COVID-19 in Canada Order (Prohibition of Entry into Canada from the United States), (Order in Council), PC 2020-0185 (26 March 2020), para d, s 5(1), online: <orders-in-council.canada.ca/attachment.php?attach=38991\& lang=en> [perma.cc/GU4T-6U3J] [OIC, 2020-0185].

6. OIC, 2020-0263, supra note 3.

7. Ravi Jain, "Re: COVID-19 and Irregular Asylum Seekers" (15 May 2020) at 2, online (pdf): Canadian Bar Association <cba.org/CMSPages/GetFile.aspx?guid=79ac3210-5ee7-425c8ac9-81bcac4acc9f> [perma.cc/9HJG-8X8V].

8. UNHCR Bureau for Europe, "Practical Recommendations and Good Practice to Address Concerns in the Context of the COVID-19 Pandemic" (9 April 2020) at 2, 8, online (pdf): <data2.unhcr.org/en/documents/download/75453> [perma.cc/DT5M-85BK] [UNHCR Europe]. 
because it has designated the US as a "safe" country for refugees. ${ }^{9}$ The litigation, which questioned the agreement's constitutionality and whether the US is, in fact, "safe" for refugees, was successful (as discussed in more detail below). ${ }^{10}$ The Federal Court recently concluded that the STCA violates section 7 of the Canadian Charter of Rights and Freedoms (the Charter), though the effect of this decision has been suspended for six months, and the federal government has announced its intention to appeal this decision. ${ }^{11}$

This article begins by introducing the STCA and several of the controversies which surround it. It will then detail how emergency powers were used to achieve a de facto extension ${ }^{12}$ of the STCA across the entire land border, extending the $S T C A$ 's application beyond the ports of entry where it previously applied. The article then discusses the surprising lack of consideration given to asylum seekers' rights by the drafters of the Quarantine Act, the inconsistent rationales advanced by the federal government for the de facto $S T C A$ extension, and how these policies violate international law. The article concludes that the de facto $S T C A$ extension was not the only option available to the government to prevent the spread of COVID-19. A better option would be to accept the Federal Court's declaration that the $S T C A$ is unconstitutional, to suspend the agreement immediately, and to allow those seeking refugee protection to cross the border subject to the regular rules for travellers, including mandatory quarantines, by revoking the provisions relating to refugees in the orders in council used to close the border. Such an approach would acknowledge mounting evidence that the US is not a safe country for refugees and would protect public health without violating Canada's legal obligations to asylum seekers.

9. Please see Part I, below, for a detailed discussion of the STCA's history and functioning.

10. See Part I(B), below.

11. Canadian Council for Refugees $v$ Canada (Immigration, Refugees and Citizenship), 2020 FC 770 at para 162 [CCR v Canada 2020]; Public Safety Canada, "Government of Canada to appeal the Federal Court decision on the Safe Third Country Agreement” (21 August 2020), online: <www.canada.ca/en/public-safety-canada/news/2020/08/government-of-canadato-appeal-the-federal-court-decision-on-the-safe-third-country-agreement.html> [perma. cc/6TX3-NPK5] [Public Safety Canada, "Government of Canada to appeal"].

12. For a discussion of this terminology, please see note 35, below, and accompanying text. 


\section{THE SAFE THIRD COUNTRY AGREEMENT}

\section{A. BACKGROUND}

The Refugee Convention requires signatories to protect individuals who arrive at their borders and meet the refugee definition. ${ }^{13}$ Regardless of how refugees travel to the country, as a signatory, Canada cannot deport them to a country where they will face persecution (doing so is known as "refoulement"). ${ }^{14}$

Safe Third Country Agreements (STCAs) allow states to return asylum seekers to countries which they have designated as "safe" instead of offering them protection (prompting some scholars to refer to STCAs as "loophole[s] in international refugee law"). ${ }^{15}$ The animating principle behind STCAs is that refugees should seek protection in the first "safe" country that they reach outside of their country of origin: A "safe" country being one that respects prohibitions against refoulement in the Refugee Convention and in the Convention Against Torture (CAT). ${ }^{16}$

The possibility of an STCA with the US first gained prominence in Canada in 1988, when Prime Minister Brian Mulroney introduced regulations intended to make it more difficult for refugees "to enter Canada in the first place." ${ }^{17}$ These reforms were criticized at that time as a plan to get the US "to do our dirty work and send the refugees back home."18

13. UNHCR, Note on International Protection, 44th session, UN Doc A/AC.96/815, August 1993 at para 11.

14. Convention Relating to the Status of Refugees, Final Act of the United Nations Conference of Plenipotentiaries on the Status of Refugees and Stateless Persons, 28 July 1951, 189 UNTS 2545, arts 31, 33, as amended by the 1967 Protocol Relating to the Status of Refugees, 189 UNTS 150 [Refugee Convention].

15. Audrey Macklin, "Citizenship, Non-Citizenship and the Rule of Law" (2018) 69 UNBLJ 19 at 38 [Macklin, 2018]. See also Isaac A Binkovitz, "State Practice with Respect to the Safe Third Country Concept: Criteria for Determining That a State Offers Effective Protection for Asylum Seekers and Refugees" (2018) 50 Geo Wash Intl L Rev 581.

16. Refugee Convention, supra note 14, art 33; Convention Against Torture and Other Cruel, Inhuman, or Degrading Treatment or Punishment, 10 December 1984, 1465 UNTS 85, art 3 (entered into force 26 June 1987); Audrey Macklin, "Disappearing Refugees: Reflections on the Canada-U.S. Safe Third Country Agreement" (2005) 36 Colum HRLR 365 at 381 [Macklin, 2005].

17. Ninette Kelley \& MJ Trebilcock, The Making of the Mosaic: A History of Canadian Immigration Policy, 2nd ed (University of Toronto Press, 1998) at 418.

18. Ibid at 419,422 . 
Although early efforts to secure an STCA with the US failed, it remained a priority for subsequent governments. ${ }^{19}$ Prime Minister Jean Chrétien finally convinced the US to commit to working towards the agreement at the end of 2001 in exchange for increased cooperation on border security. ${ }^{20}$ This was viewed by many as taking advantage of American security preoccupations in the wake of the 11 September 2001 (9/11) attacks. ${ }^{21}$ The agreement was signed in 2002, ${ }^{22}$ the US was officially designated as a safe third country in October of 2004, and the agreement went into force on 29 December 2004..$^{23}$

The $S T C A$ requires asylum seekers from other countries to make their refugee claim in the first of the two countries that they arrive. ${ }^{24}$ Accordingly, if an asylum seeker first passes through the US en route to Canada, when they arrive at a Canadian land port of entry (POE), they will be returned to the US to make their refugee claim. There are, however, a number of exceptions built into the STCA: asylum seekers who have a close family member living in Canada with lawful status, who are unaccompanied minors, or who arrived with a valid Canadian visa or entry document or were not required to obtain one may make claims in Canada. ${ }^{25}$ We will refer to these asylum seekers as "STCA exempt asylum seekers" going forward.

The STCA's coming into force led to a "dramatic drop" in the number of refugee claims made in Canada, including several thousand fewer claims made

19. Cara D Cutler, "The U.S.-Canada Safe Third Country Agreement: Slamming the Door on Refugees" (2004) 11 ILSA J Intl \& Comp L 121 at 124.

20. Howard Adelman, "Canadian Borders and Immigration Post 9/11" (2002) 36 Intl Migration Rev 15 at 27.

21. Catherine Dauvergne, "Evaluating Canada's New Immigration and Refugee Protection Act in its Global Context" (2003) 41 Alta L Rev 725 at 738; Reg Whitaker, "Refugee Policy after September 11: Not Much New” (2002) 20 Refuge 29 at 32; Macklin, 2005, supra note 16 at 371 .

22. Agreement between the Government of Canada and the Government of the United States of America For cooperation in the examination of refugee status claims from nationals of third countries, United States and Canada, 5 December 2002, Can TS 2004 No 2 (entered into force 29 December 2004) [STCA].

23. Macklin, 2005, supra note 16 at 370, 376.

24. STCA, supra note 22 at arts 1(1)(a), 4(1).

25. Ibid at art 4(2). 
at Canadian POEs. ${ }^{26}$ However, these numbers "only tell part of the story." ${ }^{27}$ The decrease in overall numbers was accompanied by an increase in border crossings between $\mathrm{POEs}^{28}$ after 2004, ${ }^{29}$ as many scholars anticipated. ${ }^{30}$ Because many asylum seekers could no longer "simply present themselves" at designated POEs to claim refugee protection "in an orderly, efficient, and safe manner," ${ }^{11}$ they were forced to rely on the STCA's limited applicability to refugee claims made at POEs. ${ }^{32}$ The STCA allows Canada and the US to return asylum seekers to their "country of last presence," defined as the country "in which the refugee claimant was physically present immediately prior to making a refugee status claim at a land border port of entry." ${ }^{33}$ Accordingly, when an asylum seeker crosses from the US to Canada between POEs, "Canada is her country of last presence under the $S T C A$," and she may advance an inland claim for refugee protection. ${ }^{34}$

While some refer to the non-application of the STCA between POEs as a "loophole," it is better understood as an intentional feature of the agreement,

26. Canadian Council for Refugees, "Closing the Front Door on Refugees: Report on the First Year of the Safe Third Country Agreement" (December 2005) at 3-5, online (pdf): $<$ ccrweb.ca/en/closing-front-door-refugees-report-first-year-safe-third-country-agreement> [perma.cc/Q47L-B975].

27. For further discussion, see Efrat Arbel, "Shifting Borders and the Boundaries of Rights: Examining the Safe Third County Agreement between Canada and the United States" (2013) 25 Intl J Refugee L 65 at 71-73.

28. Crossing into Canada "between POEs" refers to crossing into Canada from the United States by land at any place other than those entry points which have been designated as POEs by the Canadian government. Whereas previously POEs were listed in a schedule to the Immigration and Refugee Protection Regulations (IRPR), due to recent changes, discussed below, a POE is now simply defined as "a place designated by the Minister" of Public Safety and Emergency Preparedness. See Immigration and Refugee Protection Regulations, SOR/2016-37, s 2; Immigration and Refugee Protection Regulations, SOR/2020-55, s $2[$ IRPR $]$.

29. For a detailed discussion of how the STCA made the border "more dangerous and disorderly," see Efrat Arbel \& Alletta Brenner, "Bordering on Failure: Canada-U.S. Border Policy and the Politics of Refugee Exclusion" (Harvard Immigration and Refugee Law Clinical Program, November 2013) at 98-102.

30. Emily Carasco, "Canada-United States Safe Third Country Agreement: To What Purpose" (2003) 41 Can YB Intl Law 305 at 339; Macklin, 2005, supra note 16 at 398.

31. Macklin, 2018, supra note 15 at 38.

32. STCA, supra note 22, arts 1(1)(a), 4(1).

33. Ibid, art 1(1)(a).

34. Macklin, 2018, supra note 15 at 37. 
or as a "safety valve." 35 The Immigration and Refugee Protection Regulations (IRPR) explicitly state that the provisions in the Immigration and Refugee Protection Act (IRPA) which prevent claimants arriving from the US from making refugee claims $^{36}$ do "not apply to a claimant who seeks to enter Canada at a location that is not a port of entry." ${ }^{37}$ This aspect of the STCA was discussed "at some length" by the Parliamentary Standing Committee on Citizenship and Immigration (the 2002 Standing Committee) prior to the STCA's implementation. ${ }^{38}$ The Committee specifically recommended against extending the agreement across the entire land border based on evidence that Germany's STCAs had "[led] people to enter the country surreptitiously." ${ }^{39}$ The Committee feared that if the STCA applied across the entire land border it would "have an adverse effect on security and public health in Canada." ${ }^{40}$ Ultimately, the Committee recommended that the government "suspend or terminate" the STCA if "an increase in the number of illegal entries to Canada" became apparent. ${ }^{41}$

Although for many years crossings between POEs were not a major political issue in Canada, ${ }^{42}$ that changed with a "surge in asylum filings" in 2017.43 That

35. For this reason, in this article we will not refer to the government's recent actions which effectively extend the STCA's application across the entire land border as closing a "loophole" but, instead, as "the de facto STCA extension." See ibid at 35-38; Craig Damian Smith, "Changing U.S. Policy and Safe-Third Country 'Loophole' Drive Irregular Migration to Canada" (16 October 2019), online: Migration Policy Institute <www.migrationpolicy.org/ article/us-policy-safe-third-country-loophole-drive-irregular-migration-canada> [perma. cc/RW4M-XGUC].

36. Immigration and Refugee Protection Act, SC 2001, c 27, s 101(1)(e) [IRPA].

37. IRPR, supra note 28, s 159.4(1)(a). See also Statutory Instruments 2004 138/22, (2004) C Gaz II, 1624, online (pdf): Government of Canada <publications.gc.ca/gazette/archives/ p2/2004/2004-11-03/pdf/g2-13822.pdf> [perma.cc/ZQ6H-KFMS].

38. Canada, Standing Committee on Immigration and Citizenship, The Safe Third Country Regulations: Report of the Standing Committee on Citizenship and Immigration (Standing Committee on Immigration and Citizenship, 2002) (Chair: Joe Fontana) at 10 [Standing Committee on Immigration and Citizenship, 2002].

39. Ibid.

40. Ibid.

41. Ibid; STCA, supra note 22, art 10(2)-(4).

42. Macklin, 2018, supra note 15 at 41.

43. Smith, supra note 35. 
year, the RCMP intercepted 20,593 asylum seekers between official POEs. ${ }^{44}$ This surge has been ascribed partly to policy changes making the US "less hospitable" for migrants following the election of Donald Trump in 2016, ${ }^{45}$ including: the "Muslim Travel Ban," 46 pushing back asylum seekers at the US-Mexico border, ${ }^{47}$ separating children and parents in detention, ${ }^{48}$ increasing immigration detention, ${ }^{49}$ and rendering many asylum seekers fleeing gender-based persecution or gang violence ineligible for protection, amongst others. ${ }^{50}$

It is important to note that the vast majority of these crossings between POEs were not clandestine. Most asylum seekers entering the country in this way "want[ed] to get caught," and typically crossed the border openly at well-monitored locations between POEs, such as at Roxham Road. ${ }^{51}$ Upon entry, they indicated their intention to claim refugee protection and were allowed to do so as inland claimants. ${ }^{52}$ These entry points had essentially become unofficial POEs. They were considered well-managed due to standardized procedures, permanent

44. These numbers decreased to 19,419 in 2018 and to 16,503 in 2019. As of 31 August 2020, 3,143 migrants are reported as having been intercepted by the RCMP in 2020 . See Immigration, Refugees and Citizenship Canada, "Asylum claims by year" (18 August 2020), online: <www.canada.ca/en/immigration-refugees-citizenship/services/refugees/ asylum-claims.html> [perma.cc/2TSK-Q3T8] [IRCC, Asylum claims by year]. See also Immigration and Refugee Board of Canada, "Irregular border crosser statistics" (22 May 2020), online: <www.irb-cisr.gc.ca/en/statistics/Pages/Irregular-border-crosser-statistics.aspx> [perma.cc/EJ44-DTZX].

45. Smith, supra note 35.

46. See generally Ryan M Mardini, "The Muslim Ban and the Constitutional Crisis" (2019) 96 U Det Mercy L Rev 225.

47. See generally Amnesty International, "USA: 'You Don't Have Any Rights Here"” (2018), online (pdf): <www.amnesty.org/download/Documents/AMR5191012018ENGLISH.PDF> [perma.cc/78FM-W95J].

48. UN News, "UN rights chief slams 'unconscionable' US border policy of separating migrant children from parents" (18 June 2018), online: <news.un.org/en/story/2018/06/1012382> [perma.cc/EC68-HJ48].

49. Donald J Trump, "Executive Order 13767: Border Security and Immigration Enforcement Improvements" (25 January 2017), s 11(d), online: <www.whitehouse.gov/presidentialactions/executive-order-border-security-immigration-enforcement-improvements> [perma.cc/R3AB-EZWG].

50. See generally Caroline Holliday, "Making Domestic Violence Private Again: Referral Authority and Rights Rollback in Matter of A-B-" (2019) 60 Boston College L Rev 2145.

51. Macklin, 2018, supra note 15 at 29, 41.

52. Ibid at 46 . 
infrastructure, and "routinized security screening and first-line admissibility checks" by the RCMP and the Canada Border Services Agency (CBSA)..$^{53}$

The STCA is controversial for many reasons, but we will focus on two questions that have been particularly contentious in recent years. First, whether the US can be considered a safe country for refugees. Second, how to address the rise of entries between POEs.

\section{B. IS THE US SAFE FOR REFUGEES?}

The Canadian Governor-in-Council's (GIC) designation of the US as a "safe third country" has been contested for years. ${ }^{54}$ In 2007 , the Federal Court concluded that the US was not safe for refugees, and that returning asylum seekers to the US unjustifiably breached sections 7 and 15 of the Charter by exposing them to a risk of persecution or torture. ${ }^{55}$ However, the decision was overturned by the Federal Court of Appeal (FCA) for procedural reasons, including that the parties in the litigation lacked standing. ${ }^{56}$

Following President Trump's election, new litigation regarding the STCA was launched, with litigants carefully chosen to avoid the procedural problems encountered previously. ${ }^{57}$ The parties included refugee claimants who were ineligible to seek asylum in Canada because of the STCA: a Salvadoran woman and her children who were previously detained in the US and who sought asylum on the basis of gang and gender-based persecution, a Syrian family who left the US when the Muslim Travel Ban was issued by the US government, and an Ethiopian woman who was held in detention in the US for a month after she was denied entry to Canada. ${ }^{58}$

53. It is important to note that despite RCMP and CBSA presence, entering Canada at Roxham Road qualifies as entering Canada "between POEs." Although Roxham Road was "the site of a former designated port of entry that closed several years ago," it has not been re-designated as a POE since. The Canadian government has refrained from designating these sites as POEs, presumably because doing so would simply lead asylum seekers to cross at less well-monitored locations. Macklin, 2018, supra note 15 at 29, 41; Smith, supra note 35.

54. IRPA, supra note 36, s 102(1).

55. Canadian Council for Refugees v R, $2007 \mathrm{FC} 1262$ at paras 51, 240, 338.

56. Canadian Council for Refugees $v$ Canada, 2008 FCA 229 at paras 98-103, leave to appeal to SCC refused, 32820 (5 February 2009). For a detailed discussion of this litigation, see Arbel, supra note 27 at 78-84.

57. For a discussion of these problems, see ibid at 81-84; Macklin, 2018, supra note 15 at 40-41; Canadian Council for Refugees v Canada, 2018 FC 829 at para 5.

58. Canadian Council for Refugees $v$ Canada (Immigration, Refugees and Citizenship), 2020 FC 770 (CanLII) (Applicant's Further Memorandum of Fact and Law, paras 37-43) (on file with the authors). 
The applicants challenged the provisions of the IRPA which designated the US as a safe third country ${ }^{59}$ and which render claimants travelling from the US ineligible to have their refugee claims considered in Canada on several grounds. ${ }^{60}$ Their arguments focused on multiple "aspects of the U.S. asylum system that limit the protection accessible to broad classes of refugees, exposing them to refoulement in violation of the Refugee Convention." 61 They provided extensive evidence on these aspects of the US refugee system, including on a policy called the "one year bar" which imposes a higher risk standard than does the Refugee Convention for claimants who do not make their claim within a year of arriving in the country, ${ }^{62}$ on policies which effectively place women fleeing gender-based-persecution "outside the refugee definition," 33 on an "overly restrictive legal interpretation" of the particular social group ground of asylum which increases the risk of refoulement for "those fleeing harm based on their sexual orientation, gender identity, or gang targeting," ${ }^{4}$ on the practice of criminally prosecuting "illegal" entry into the US of asylum seekers, ${ }^{65}$ on the use of an "expedited removal process" which denies many asylum seekers an opportunity to claim asylum, ${ }^{66}$ and on a series of policies at the US-Mexico border which illegally pushes asylum seekers back and/or forces them to wait in Mexico "for months or years" until their US asylum hearing. ${ }^{67}$ The applicants also provided extensive evidence on American immigration detention conditions, including evidence about "the large-scale detention of children and the mass separation of children and parents," ${ }^{\prime} 8$ evidence that asylum seekers "regularly remain detained throughout the asylum process," ${ }^{69}$ evidence that being detained in this way "seriously impedes asylum-seekers' ability to mount an asylum claim, ${ }^{70}$ and evidence that detention conditions

59. IRPR, supra note 28, s 159.3 .

60. IRPA, supra note 36, s 101(1)(e). The applicants sought declarations that these provisions were ultra vires, inconsistent with Canada's obligations under the Refugee Convention and the CAT and in violation of sections 7 and 15 of the Charter. CCR $v$ Canada, 2020, supra note 11 at para 28 .

61. CCR v Canada, Applicant's Memo, supra note 58 at para 16.

62. Ibid at paras 32-36.

63. Ibid at para 37.

64. Ibid at para 42 .

65. Ibid at para 44 .

66. Ibid at para 47.

67. Ibid at paras 53-54.

68. Ibid at para 26 .

69. Ibid at para 19 .

70. Ibid at para 22. 
were "often inhumane, cruel and unusual." ${ }^{11}$ We note that, because the case was heard prior to the global pandemic, no evidence connected to COVID-19 was before the court.

In July 2020, several months into the pandemic, the Federal Court released its decision in the Canadian Council for Refugees $v$ Canada (CCR $v$ Canada) case. In its decision, the court was careful not to "pass judgement on the US asylum system" or to engage in "a comparison" of Canadian and American asylum systems. ${ }^{72}$ The court rejected a line of arguments that focused on the reasonableness of designating the US as a safe third country ${ }^{73}$ and declined to address a line of arguments focused on the STCA's disproportionate impact on women. ${ }^{74}$ However, the court agreed with the applicants that the provisions implementing the STCA violated constitutional rights to life, liberty, and security of the person under section 7 of the Charter. The court concluded these violations could not be justified in a free and democratic society under section $1 .{ }^{75}$

The analysis in CCR $v$ Canada was largely focused on the evidence with respect to US detention conditions outlined above. The court concluded that "the immediate consequence to ineligible STCA claimants is that they will be imprisoned solely for having attempted to make a refugee claim in Canada." ${ }^{76}$ The court's analysis centred on the evidence of what befell one of the applicants,

71. The conditions described by the applicants included "punitive conditions; Solitary confinement; Inadequate and/or delayed medical care ...; Staggering rates of sexual assault and sexual harassment; Dangerous overcrowding; Cold temperatures; Inadequate/unsafe food/water and lack of accommodation of religious dietary customs; Limited or no time outdoors." Ibid at para 24.

72. CCR v Canada, 2020, supra note 11 at para 138.

73. The applicants argued that the relevant provisions were ultra vires, or beyond the government's lawful authority. The court concluded that it could not depart from the "binding authority" of the Federal Court of Appeal's (FCA) 2008 decision on this matter. While the Federal Court concluded in 2007 that the STCA's failure to comply with relevant provisions of the Refugee Convention and the CAT was a condition precedent to the GIC's exercise of its delegated authority under s 102 of the IRPA, the FCA found that it was "irrelevant" if the US "actually" complied with these conventions as long as the Canadian government considered the factors set out in s 102(2) of the IRPA. For a detailed discussion of these decisions, see Arbel, supra note 27 at 79-82. CCR $v$ Canada, 2020, supra note 11 at paras 79-80.

74. The applicants also argued that the STCA violates s 15 of the Charter "because it has a disproportionate impact on women" due to US asylum law's effective exclusion of asylum claims founded on gender-based persecution. The court declined to address this challenge in light of its ruling with respect to section 7 . For further discussion of the arguments advanced with respect to s 15, see Part III(D). See CCR v Canada, 2020, supra note 11 at para 154.

75. Ibid at para 162 .

76. Ibid at para 128 . 
Ms. Mustefa. After trying to claim asylum in Canada and being found ineligible because of the STCA, Ms. Mustefa was returned to the US by CBSA officers, was then "immediately imprisoned," held in solitary confinement for a week, lost nearly fifteen pounds because she was being fed pork "despite telling the guards she could not consume it for religious reasons," and was "detained alongside people who had criminal convictions." 77 The court found that this evidence was sufficient to "shock the conscience," that it "clearly demonstrate[d] that those returned to the US by Canadian officials are detained as a penalty" without "regard for their circumstances, moral blameworthiness, or their actions," and that these actions were "not in keeping with the spirit or the intention of the STCA or the foundational Conventions upon which it was built." concluded that the liberty rights in section 7 of the Charter were breached, that "Canada cannot turn a blind eye to the consequences that befell Ms. Mustefa in its efforts to adhere to the $S T C A$," and that "the risk of detention for the sake of 'administrative' compliance with the provisions of the STCA cannot be justified." 79

The court concluded by declaring the relevant provisions of the IRPA and the $I R P R$ to be of no force and effect but suspended the effect of its decision for six months to "allow time for Parliament to respond."

The Minister of Public Safety and Emergency Preparedness, Bill Blair, has recently announced that the federal government intends to appeal this decision, citing unspecified "factual and legal errors" in CCR $v$ Canada and reiterating that "people should claim asylum in the first safe country in which they arrive." ${ }^{11}$ This issue will accordingly remain live for at least some time. We will further address several of the arguments considered in CCR $v$ Canada below.

\section{HOW SHOULD THE “SURGE" IN ENTRIES BETWEEN POES BE ADDRESSED?}

In addition to questions about the constitutionality of the $S T C A$, there has also been significant controversy about how to address the rise in asylum seekers supposedly "illegally" entering Canada using the so-called "loophole" in the STCA. ${ }^{82}$

77. Ibid at paras 92-96.

78. Ibid at paras $135-39$.

79. Ibid at paras 103-15.

80. Ibid at paras $162-63$.

81. Public Safety Canada, "Government of Canada to appeal," supra note 11.

82. For a discussion of why it is inaccurate to call entering between POEs a "loophole," see notes 35 to 41 and accompanying text. 
Before examining that controversy, we wish to highlight that it is not "illegal" for asylum seekers to enter Canada between official POEs. International law recognizes the right to seek asylum, ${ }^{83}$ and the Refugee Convention prohibits signatories from imposing "penalties" on refugees who have entered "without authorization." ${ }^{84}$ Until recently, the only technically "illegal" act that an asylum seeker made when crossing the border between official POEs was their failure to declare imported goods. ${ }^{85}$

In response to the 2017 "surge" described above, many have called for the STCA's suspension. ${ }^{86}$ Some have specifically questioned why the government did not "heed the recommendation" of the 2002 Standing Committee to suspend the agreement once "an increase in the number of illegal entries to Canada" had become apparent. ${ }^{87}$

At the same time, members of the Conservative Party objecting to "illegal border crossers" from the US ${ }^{88}$ have sought to declare the entire land border with the US a POE, thus unilaterally expanding the $S T C A .{ }^{89}$ It is difficult to understand how this could have been implemented. While either country may terminate or suspend the STCA unilaterally, any modifications or additions must be agreed to in writing. ${ }^{90}$ Without the US's consent to return these asylum seekers, the US could—and likely would—simply refuse to re-admit them.

83. Universal Declaration of Human Rights, GA Res 217A (III), UNGAOR, 3rd Sess, Supp No 13, UN Doc A/810 (1948) 71, art 14. For further discussion, see Jane McAdam \& Kate Purcell, "Refugee Protection in the Howard Years: Obstructing the Right to Seek Asylum" (2008) 27 Australian YB of Intl L 87 at 90-92.

84. Refugee Convention, supra note 14 , art 31.

85. Changes to be discussed in detail in Part III(G), below. See Macklin, 2018, supra note 15 at 31, 46-47.

86. The Canadian Press, "Quebec should have power over Ottawa in refugee settlement: Bloc Quebecois leader,” Global News (23 September 2019), online: <globalnews.ca/ news/5940238/bloc-quebecois-leader-calls-for-suspension-of-safe-third-country-agreement> [perma.cc/A3AR-LRAN]; Jenny Kwan, "NDP Statement on Safe Third Country Agreement" (15 March 2019), online: NDP <www.ndp.ca/news/ndp-statement-safe-third-countryagreement> [perma.cc/FP25-TAUR].

87. Macklin, 2018, supra note 15 at 43; Standing Committee on Immigration and Citizenship, 2002, supra note 38 at 10 .

88. Conservative Party of Canada, "A new Conservative government will close the loophole in the Safe Third Country Agreement" (9 October 2019), online: <www.conservative. ca/a-new-conservative-government-will-close-the-loophole-in-the-safe-third-countryagreement> [perma.cc/QCP5-U36J].

89. Brian Hill, "Experts say Scheer's plan to close border loophole 'doomed to failure," Global News (9 October 2019), online: <globalnews.ca/news/6011333/scheer-plan-borderloophoole-doomed-to-failure-experts> [perma.cc/UBB7-DBHR].

90. STCA, supra note 22 at art 10 , s $2-4$. 
Ultimately, the Liberal government chose to neither suspend nor unilaterally expand the STCA. Instead, the Prime Minister's most recent mandate letter of the IRCC Minister included a commitment to "work with the United States to modernize" the STCA. ${ }^{91}$ Although the current IRCC Minister refused to confirm whether "modernize" meant "that the government is looking for ways to extend and expand" the STCA, ${ }^{92}$ and the former IRCC Minister indicated that there was "no need to tinker" with the $S T C A,{ }^{93}$ it is clear that efforts have long been underway to "review" the agreement with the US. ${ }^{94}$ Indeed, Minister Blair has indicated that Canada was "hoping to address" the "exemption" in the STCA allowing people "to avoid its terms" in "ongoing discussions" with the US. ${ }^{95}$ However, little progress was made on this front. ${ }^{96}$ This is unsurprising. The Trump administration has little interest in preventing asylum seekers from leaving the US for Canada.

\section{THE DE FACTO EXTENSION OF THE STCA ACROSS THE ENTIRE LAND BORDER}

Despite American reluctance, the goal of negotiating away the STCA "exemption" has nonetheless been temporarily achieved during the COVID-19 crisis. Media reports suggest that the US has agreed to the de facto STCA extension during the

91. Justin Trudeau, "Minister of Immigration, Refugees and Citizenship Mandate Letter" (13 December 2019), online: Office of the Prime Minister <pm.gc.ca/en/mandate-letters/ 2019/12/13/minister-immigration-refugees-and-citizenship-mandate-letter>.

92. The Minister answered that modernize "means to continually reassess this agreement." House of Commons, Standing Committee on Citizenship and Immigration, Minutes of Proceedings and Evidence, 43-1, No 5 (12 March 2020) at 6, online: Our Commons <www.ourcommons. ca/DocumentViewer/en/43-1/CIMM/meeting-5/minutes> [perma.cc/F7TV-DPML].

93. Brenna Rose, "Safe Third Country Agreement to stay, pledges immigration minister," CBC News (29 March 2019), online: <www.cbc.ca/news/canada/british-columbia/ safe-third-country-agreement-to-stay-pledges-immigration-minister-1.4046998>.

94. Rachel Aiello, "Border security minister engages U.S. in formal Safe Third Country talks," CTV News (23 September 2018), online: <www.ctvnews.ca/politics/border-security-ministerengages-u-s-in-formal-safe-third-country-talks-1.4104602> [perma.cc/DEW7-TAPY].

95. Teresa Wright, "Blair mulling ways to close loophole in Safe Third Country Agreement," National Observer (17 March 2019), online: <www.nationalobserver.com/2019/03/17/news/ blair-mulling-ways-close-loophole-safe-third-country-agreement> [perma.cc/CX66-4F3H].

96. Amanda Connolly, "U.S. inches closer to allowing talks to amend Safe Third Country Agreement," Global News (1 April 2019), online <globalnews.ca/news/5119022/ safe-third-country-agreement-amend-united-states> [perma.cc/9VYY-RW4J]. 
global pandemic. ${ }^{97}$ The extension will likely remain in effect until all appeals of CCR $v$ Canada are concluded.

Unfortunately, despite pressure from activists, the government has refused to make agreements or negotiations with the US on these matters public. ${ }^{98}$ Their effects can nonetheless be tracked through a series of Orders in Council (OICs) released by the GIC pursuant to the Quarantine Act to prevent "non-essential" foreign nationals from entering Canada. ${ }^{99}$

\section{A. ORDERS IN COUNCIL AND ALTERED REGULATIONS}

The first OIC, issued on 20 March 2020, prohibited most foreign nationals from entering Canada from the US "for the purpose of making a claim for refugee protection," both at and between POEs. ${ }^{100}$ This broad ban on asylum seekers' entry continued through subsequent OICs. ${ }^{101}$ Then, on 20 April 2020, the government once again permitted asylum seekers who met STCA exemptions to seek asylum at official POEs, but introduced sweeping measures prohibiting most foreign nationals from entering Canada through the US "for the purpose of making a claim for refugee protection unless" they specifically sought "to enter Canada at a land [POE] designated by the Minister of Public Safety and Emergency Preparedness." ${ }^{102}$

This OIC activated three relevant sections of the IRPR which were amended a month earlier to authorize the CBSA "to operationalize the prohibitions" made in all subsequent OICs pursuant to the Quarantine Act or the Emergencies Act. ${ }^{103}$

97. Brooklyn Neustaeter, "Canada-U.S. border to remain closed to non-essential travel for another month," CTV News (16 June 2020), online: <www.ctvnews.ca/health/coronavirus/ canada-u-s-border-to-remain-closed-to-non-essential-travel-for-another-month-1.4986310> .

98. Nicholas Keung, "Ottawa should reveal details of border ban," Toronto Star (11 May 2020), online: <www.thestar.com/news/gta/2020/05/11/ottawa-should-reveal-details-ofborder-ban-on-irregular-migrants-refugee-advocates-say.html> [perma.cc/YK33-KJMP] [Keung, "Border Ban"].

99. Quarantine Act, SC 2005, c 20, s 58 [Quarantine Act].

100. OIC, 2020-0161, supra note 2, s 4(1).

101. OIC, 2020-0185, supra note 5, s 5(1).

102. OIC, 2020-0263, supra note 3, s 5(1). These same measures have been replicated in subsequent orders, including the most recent OIC, effective until 21 September 2020. Canada, Minimizing the Risk of Exposure to COVID-19 in Canada Order (Prohibition of Entry into Canada from the United States), (Order in Council), PC 2020-0565 (20 August 2020), s 5(1), online: <orders-in-council.canada.ca/attachment.php?attach=39536\&lang=en> [perma.cc/666U-9ZA4].

103. IRPR, supra note 28; Statutory Instruments 2020 154/8, (2020) C Gaz II, 554-55, online: Government of Canada <canadagazette.gc.ca/rp-pr/p2/2020/2020-04-15/pdf/g2-15408. pdf> [Canada Gazette, 2020]. 
First, part of the definition of a POE was repealed so that it was now simply defined as "a place designated by the Minister" as a POE. ${ }^{104}$ Secondly, the Minister was granted full discretion to designate POEs in response to new OICs issued pursuant to the Quarantine Act or the Emergencies Act. ${ }^{105}$ Finally, foreign nationals "prohibited from entering Canada by" one of these OICs were added to the list of those who CBSA officers could "direct back" to the US. ${ }^{106}$

Previously, IRCC guidance indicated that CBSA officers could only temporarily direct refugee claimants back to the US "under exceptional circumstances" and only after making "[a]ll efforts" to process them at the time of arrival. ${ }^{107}$ In those circumstances, officers were required to schedule an appointment within three working days and to seek "assurances from" US Customs and Border Protection (CBP) that the claimant would be made available to return for their appointment. ${ }^{108}$

The changes to the direct back provisions significantly expand their potential use and application. According to a recent CBSA Operational Bulletin, all foreign nationals not falling under one of the prescribed exemptions to the OICs are to be directed back to the US "until the order is lifted." 109 The Bulletin indicates that those who comply with the direct backs will be allowed to "return to the border to seek entry after the prohibitions have been lifted," 110 but that those who fail to comply or who attempt to re-enter before the OICs are lifted "after being directed back" will be rendered inadmissible to Canada for non-compliance with the IRPA. ${ }^{111}$ Asylum seekers entering the country between POEs appear to be caught by this policy; ${ }^{112}$ the bulletin specifically mentions foreign nationals "intercepted between" POEs amongst those to be directed back to the US. ${ }^{113}$

104. See discussion above at note 28. See also Canada Gazette, 2020, supra note 103 at 556.

105. IRPR, supra note 28, s 26(f).

106. Ibid, s 41(d).

107. Immigration, Refugees and Citizenship Canada, "ENF 4 Port of Entry Examinations" (15 August 2019) at 98, online (pdf): <www.canada.ca/content/dam/ircc/migration/ircc/english/ resources/manuals/enf/enf04-eng.pdf> [perma.cc/SV3S-RKNX].

108. Ibid at 99.

109. Canada Border Services Agency, Regulatory Amendments to Implement Travel Prohibitions in Response to the Covid-19 Pandemic, (Operational Bulletin), OBO-2020-021 (21 March 2020) at 2 [CBSA, OBO-2020-021].

110. Ibid at 4 .

111. Ibid.

112. Please note that we cannot speak definitively —we are aware of a separate bulletin which apparently provides instructions for officers dealing with all "foreign nationals who make a claim for refugee protection." This bulletin has not been made publicly available. We have made an Access to Information Request in hopes of obtaining it. Ibid at 3.

113. Ibid at 4 . 
Taken together, the three changes to the IRPR outlined above effectively ensure that designated POEs are the only places where asylum seekers may currently enter the country. Similarly, the relevant OICs ensure that only STCA exempt asylum seekers will be admitted at designated POEs. This means that the STCA is currently being enforced in a manner that is even more restrictive than when the Federal Court heard evidence which led the court to declare the agreement unconstitutional.

As discussed above, closing the Canada-US border to asylum seekers entering between POEs can only be achieved with the US's consent. Although the terms of the current arrangements with the US are not publicly known, Canada has achieved its objective of ending border crossings between POEs, at least temporarily, by leveraging the COVID-19 crisis to surmount apparent US reluctance. The result is that the Canadian government has effectively barred most refugee claimants from entering Canada. ${ }^{114}$

It is worth noting the striking parallels between the present moment and the moment which initially motivated the US to sign the STCA. Just as the Canadian government took advantage of American preoccupations with national security after 9/11 to convince the US to agree to the STCA in 2001, today Canada has leveraged a global pandemic to persuade the US to (at least temporarily) agree to the de facto extension of the STCA. ${ }^{115}$

Perhaps we should not be surprised. Pandemic planning has long invoked analogies "between contagious disease and terrorism; between the individual carrier of disease and the terrorist intent on destruction." 116 As Janet Mosher has observed, "[b]oth are depicted as threats to national security, and best managed through surveillance, borders, containment, and control." ${ }^{117}$

\section{B. LEGISLATIVE INTENT AND THE QUARANTINE ACT}

The use of the Quarantine Act to close the border to most refugees raises the question: do these actions align with the purposes of the Act?

114. For details of how other refugees have been blocked from coming to Canada, including some resettled refugees, see Immigration, Refugees and Citizenship Canada, "Coronavirus disease (COVID-19): Refugees, asylum complaints, sponsors and PRRA applicants” (25 May 2020), online: <www.canada.ca/en/immigration-refugees-citizenship/services/coronavirus-covid19/ refugees.html\#resettlement> [perma.cc/T3MF-79RW].

115. See notes 18-19 and accompanying text, above. See also Cutler, supra note 19 at 125.

116. Janet E Mosher, "Accessing Justice amid Threats of Contagion" (2014) 51 Osgoode Hall LJ 919 at 921.

117. Ibid. 
The power to prohibit classes of persons from entering Canada in response to public health risks was introduced following the 2003 SARS outbreak. The Minister of Health introduced a revised Quarantine Act in 2005 empowering the GIC to prohibit "any class of persons" from entering Canada if "the entry of members of that class of persons" might "introduce or contribute to the spread of" a communicable disease and "no reasonable alternatives" were available to prevent such a spread. ${ }^{118}$

The drafters of the Act do not appear to have discussed the impact of such a closure on asylum seekers in committee or parliamentary debates. The only mention of refugees in these discussions was an assertion about the need for "clarity around whether this Act will be paramount to" the IRPA. ${ }^{119}$ There appears to have been no consideration of what "reasonable alternatives to prevent the introduction or spread of the disease" needed to be considered before excluding a whole class of people from the country.

However, the drafters did speak of wanting to strike the "proper balance between the need to protect public health and the need to protect human rights." 120 They took pains to ensure that those enforcing the Act would "always choose the least intrusive measure" available. ${ }^{121}$ We may therefore conclude that the drafters assumed that this "extreme measure" would only be implemented if it struck the proper balance between the human rights of those being excluded and the need to protect public health. ${ }^{122}$ In our view, the de facto STCA extension has not achieved this balance.

118. Nola M Ries, "Quarantine and the Law: The 2003 SARS Experience in Canada (A New Disease Calls on Old Public Health Tools)" (2005) 43 Alta L Rev 529 at 535; Quarantine Act, supra note 99, s 58.

119. House of Commons, Standing Committee on Health, Evidence, 38-1, No 9 (23 November 2004) 1 at 2, online (pdf): OurCommons <www.ourcommons.ca/Content/Committee/381/ HESA/Evidence/EV1498032/HESAEV09-E.PDF> [perma.cc/V6CS-U2UY].

120. House of Commons, Standing Committee on Health, Evidence, 38-1, No 6 (4 November 2004) at 6, online (pdf): OurCommons <www.ourcommons.ca/Content/Committee/381/ HESA/Evidence/EV1460081/HESAEV06-E.PDF> [perma.cc/6KB3-SD7D].

121. Ibid at 6 .

122. Ries, supra note 118 at 535. 


\section{IMPACT OF THE DE FACTO STCA EXTENSION TO DATE}

Between 21 March and 12 May 2020, twenty-six asylum seekers were directed back to the US after attempting to enter Canada between POEs. ${ }^{123}$ For context, the RCMP intercepted 1,246 asylum seekers in April of 2019, and 1,196 in May of 2019. ${ }^{124}$ These numbers indicate that either fewer asylum seekers are entering from the US during COVID-19, or, as the 2002 Standing Committee feared, that more asylum seekers are simply avoiding detection upon entry.

Like many refugee advocates, we fear that Canada's emergency measures may lead to the refoulement of asylum seekers, in violation of international law. ${ }^{25}$ It remains unclear whether the US has committed not to deport returned asylum seekers, but some American officials have indicated that they "will immediately" deport "illegal aliens." 126 Further, as discussed briefly in Part I(B), above, the Federal Court confirmed in CCR $v$ Canada that "the immediate consequence to ineligible STCA claimants" of being denied entry to Canada is "that they will be imprisoned solely for having attempted to make a refugee claim in Canada," and that this detention takes place "without regard to their circumstances, moral blameworthiness, or their actions." 127 The Federal Court also characterized detention conditions as "cruel and usual," even without considering evidence of

123. Daniel Renaud, "Le nombre de demandeurs d'asile en chute libre," La Presse (13 May 2020), online: <www.lapresse.ca/covid-19/202005/12/01-5273336-le-nombre-de-demandeursdasile-en-chute-libre.php> [perma.cc/ZP2B-QS23]. See also Stephanie Levitz, "CBSA says it turned back 21 asylum seekers who tried to cross from U.S. in May," The Globe and Mail (29 June 2020), online: <www.theglobeandmail.com/canada/article-cbsa-says-it-turned-back-21asylum-seekers-who-tried-to-cross-from-us> [perma.cc/W88Y-HJNV].

124. IRCC, Asylum claims by year, supra note 44.

125. Keung, "Border Ban," supra note 98.

126. Department of Homeland Security, "Fact Sheet: DHS Measures on the Border to Limit the Further Spread of Coronavirus" (23 March 2020), online: <www.dhs.gov/news/2020/05/20/ fact-sheet-dhs-measures-border-limit-further-spread-coronavirus> [perma.cc/MB7W-XZAF] [DHS]. See also Reuters, "Asylum-seekers turned back by Canada at its border will be shipped home, U.S. says," National Post (27 March 2020), online: <nationalpost.com/news/ canada/u-s-to-return-canada-bound-asylum-seekers-stopped-at-border-to-home-nations> [perma.cc/PW46-BFP6].

127. CCR v Canada, 2020, supra note 11 at paras 128, 135. 
heightened risks during COVID-19. ${ }^{128}$ In our view, the American response to the pandemic has only amplified the concerns that led the Federal Court to find the STCA unconstitutional.

\section{SOME OF THE BIGGEST PROBLEMS WITH THE DE FACTO EXTENSION OF THE STCA}

We acknowledge that responsible governments must "take legitimate measures to prevent the spread of the virus." ${ }^{129}$ In a similar acknowledgment, the UNHCR issued two documents which provide guidance on how states can achieve "an effective response to the pandemic while at the same time respecting international refugee law and standards." ${ }^{130}$ The first outlines "key legal considerations, based on international refugee and human rights law" which states should consider if they "restrict the entry of non-nationals for the protection of public health in response to the COVID-19 pandemic." ${ }^{31}$ The second, issued by the UNHCR's Regional Bureau for Europe, provided governments with "a set of practical considerations and concrete advice to enable an effective response to the pandemic while at the same time respecting international refugee law and standards." 132

In our view, the measures adopted by the Canadian government fail to respect the international standards reflected in these documents in four key respects: (1) they appear to penalize asylum seekers for "illegal" entry; (2) they are not clearly "necessary for the legitimate purpose of managing the identified health risk"; 133 (3) they do not provide any mechanism for making "independent inquiries"

128. Ibid at para 136. See generally Amnesty International, "USA: 'We are Adrift, About to Sink': The Looming COVID-19 Disaster in the United States Immigration Detention Facilities" (April 2020), online (pdf): <www.amnesty.org/download/Documents/ AMR5120952020english.pdf> [perma.cc/R3R6-9EJ7]; Immigration and Customs Enforcement, "ICE Detainee Statistics" (5 June 2020), online: <www.ice.gov/coronavirus> [perma.cc/BZ4A-WK5E]; Patricia Sulbarán Lovera, "Coronavirus: Immigration detention centres in crisis," BBC News (1 May 2020), online: <www.bbc.com/news/world-us-canada52476131> [perma.cc/T55A-5J97].

129. UNHCR Europe, supra note 8 at 1.

130. Ibid.

131. UNHCR, "Key Legal Considerations on access to territory for persons in need of international protection in the context of the COVID-19 response" (16 March 2020) at para 5, online: <data2.unhcr.org/en/documents/details/75349> [perma.cc/BC7B-X2GH] [UNHCR, COVID-19].

132. UNHCR Europe, supra note 8 at 1.

133. UNHCR, COVID-19, supra note 131 at para 7. 
to ensure that persons arriving at their borders "are not at risk of refoulement"; ${ }^{134}$ and (4) they do not abide by the requirement that "measures to ascertain and manage risks to public health ... must be non-discriminatory," ${ }^{135}$ as they will likely amplify the STCA's disproportionate impact on female asylum seekers, particularly those fleeing gender-based persecution.

\section{A. DO THE MEASURES PENALIZE ASYLUM SEEKERS FOR THEIR METHOD OF ENTRY?}

Our first concern with the de facto STCA extension is that it penalizes asylum seekers for entering the country irregularly. CBSA directives reveal that asylum seekers who enter the country between POEs may be charged by the RCMP with "non-compliance with the Quarantine Act prohibition on non-essential travel" (which carries a fine of up to $\$ 750,000$ and/or imprisonment for up to six months), or may be directed back to the US by the CBSA. ${ }^{136}$ This is a dramatic departure from previous Canadian practice, where the only thing "illegal" about these crossings was a minor breach of the Customs Act. ${ }^{137}$

These changes appear to contravene article 31(1) of the Refugee Convention, which prohibits state parties from "impos[ing] penalties, on account of their illegal entry or presence, on refugees who ... enter or are present in their territory without authorization." 138 These prohibitions are reflected in the IRPA: Section 133 prevents refugees and refugee claimants from being charged for certain crimes "in relation to [their] coming into Canada." ${ }^{39}$ However, these protections are limited to select offences under the IRPA and the Criminal Code of Canada. ${ }^{140}$ The government's failure to include the new Quarantine Act offences under this provision's protection means that asylum seekers could face fines or imprisonment for coming into Canada to claim refugee protection.

Even if asylum seekers are not charged, directing them back to the US for breaching the Quarantine Act is itself a penalty. The Supreme Court of Canada

134. Ibid at para 3 .

135. Ibid at para 5.

136. CBSA, OBO-2020-021, supra note 109 at 2, 4-5; Royal Canadian Mounted Police, "News Release: RCMP role in enforcing the Federal Quarantine Act" (10 April 2020), online: <www.rcmp-grc.gc.ca/en/news/2020/rcmp-role-enforcing-the-federal-quarantine-act> [perma.cc/ZK96-4494]; Quarantine Act, supra note 99, s 71.

137. See Macklin, 2018, supra note 15 at 46-48.

138. Refugee Convention, supra note 14, art 31(1).

139. Uppal v Canada (Minister of Citizenship and Immigration), 2006 FC 338 at para 21.

140. IRPA, supra note 36, s 133. 
has confirmed that article 31 does not apply "only to criminal penalties." ${ }^{141}$ International refugee law expert James Hathaway has described a US practice of placing some asylum seekers who arrive irregularly into expedited removal processes with reduced procedural rights as "a penalty inflicted for irregular entry" because the procedure is designed "to sanction a refugee for his or her mode of entry." "142 The OICs and the changes to the IRPR should similarly be understood as "penalties" which violate the Refugee Convention; they effectively prevent claimants from accessing regular refugee claim procedures as punishment for violating the Quarantine Act.

\section{B. ARE THE MEASURES STRICTLY NECESSARY?}

Secondly, several international instruments provide guidance on when and how border closures should be implemented in the context of public health crises. As a signatory to the International Health Regulations (IHR), Canada was required to provide the World Health Organization (WHO) with a public health rationale supported by scientific evidence before implementing measures that interfered with international traffic. ${ }^{143}$ Similarly, the International Covenant on Civil and Political Rights $(I C C P R)$ requires "clear and convincing evidence that the person whose rights are to be curtailed ... poses a demonstrable threat to others; that the burden is proportionate to the expected benefit ... and that the measure is applied in a non-discriminatory manner." ${ }^{144}$ The UNHCR reiterated these requirements, indicating that "measures to ascertain and manage risks to public health" must be "non-discriminatory as well as necessary, proportionate, and reasonable to the aim of protecting public health." 145 The Canadian government has failed to publicly offer a clear and consistent rationale explaining why the de facto STCA extension is an effective means of protecting public health or that it has met the obligations outlined above.

Three days before the de facto STCA extension was implemented, Minister Blair indicated that asylum seekers would continue to be allowed into the country, but that they would be screened for symptoms and isolated for fourteen days. ${ }^{146}$

141. B010 v Canada (Citizenship and Immigration), 2015 SCC 58 at para 63.

142. James C Hathaway, The Rights of Refugees under International Law (Cambridge University Press, 2005) at 408.

143. World Health Organization, International Health Regulations, 2nd (WHO, 2005), art 43.3.

144. Mosher, supra note 116 at 932.

145. UNHCR, COVID-19, supra note 131 at para 5.

146. Canadian Public Affairs Channel, "Ministers and Federal Health Officials Provide COVID-19 Update” (17 March 2020) at 23m:23s, online: <www.cpac.ca/en/programs/ covid-19-canada-responds/episodes/66171692> [perma.cc/258L-92V9]. 
This initial plan would have aligned with the UNHCR's recommendations that states manage the arrival of asylum-seekers in a safe manner by implementing "an explicit exemption for asylum seekers" where "entry bans or border closures are implemented," alongside quarantine and medical screening or testing practices. ${ }^{147}$

As discussed above, the government changed course dramatically only a few days later, initially banning the entry of all asylum seekers and subsequently carving out exceptions exclusively for STCA exempt asylum seekers. Federal officials have advanced conflicting rationales for the subsequent change of policy. Policy documents indicate that the measures were introduced to prevent the entry of those who "may pose a health and safety risk to Canada." 148 Although Minister Blair has acknowledged that asylum seekers "do not represent a higher public health risk," he has also said that the expansion is intended "to keep people safe" 149 and to "ensure the safety of Canadians." 150 Similarly, the Prime Minister has stated that the changes were "not at all" due to a lack of space or resources, ${ }^{151}$ but Minister Blair insisted they were necessary to "manage and regulate non-essential passage" at the border. ${ }^{152}$

Whatever the true rationale, the measures taken perpetuate a troubling history whereby refugees "have been identified as vectors of disease, scapegoated ... and banished." ${ }^{153}$ As Mosher posits, the question of which laws are necessary in the context of a pandemic "can only be answered by interrogating more closely how the threat is conceptualized and who is understood to be threatened." 154 It is clear that asylum seekers have been presented as a threat to "the health of Canadians," but it is not clear why, particularly in light of evidence that migrants

147. UNHCR Europe, supra note 8 at 1-2.

148. Canada Gazette, 2020, supra note 103 at 555.

149. Canadian Public Affairs Channel, "Federal Ministers and Health Officials Provide COVID-19 Update” (20 March 2020) at 1h:16m:30s, online (video): <www.cpac.ca/en/ programs/covid-19-canada-responds/episodes/66172917> [perma.cc/FUP4-3JKP] [CPAC, 20 March 2020].

150. ParlVU, "Meeting No. 2 Special Committee on the COVID-19 Pandemic" (29 Apr 2020) at 13h:28m, online (video): <parlvu.parl.gc.ca/Harmony/en/PowerBrowser/ PowerBrowserV2/20200429/-1/33109?Language=English\&Stream=Video $>$ [perma.cc/ EQ34-9DJW] [COVID-19 Committee, Meeting 2].

151. CPAC, 20 March 2020, supra note 149 at 00h:01m:02s.

152. Ibid at 00h:09m:09s.

153. Mosher, supra note 116 at $936-37$.

154. Ibid at 920-21. 
and refugees have "a low risk of transmitting communicable diseases to host populations in general." 155

International organizations have warned that rather than protecting public health, travel restrictions during pandemics can "be detrimental to disease prevention efforts." 156 Indeed, the WHO has written that, although "border closure may seem an attractive political option to prevent the spread of a communicable disease across international land borders, evidence that closing a border is an effective disease prevention measure is scant-to-nonexistent." 157 Rather than preventing the spread of disease, the WHO writes that border closures "can have the opposite effect of increasing the risk of spread by encouraging travellers to take uncontrolled routes across the border." ${ }^{158}$ The WHO accordingly encourages states to avoid border closures in favour of measures which "would achieve a similar level of health protection." ${ }^{59}$ Similarly, the UNHCR has argued that precluding the admission of refugees or asylum-seekers "without evidence of a health risk and without measures to protect against refoulement, would be discriminatory and would not meet international standards." 160

Given these warnings and the government's failure to provide a reasonable or consistent rationale for targeting asylum-seekers entering between POEs, we believe that the de facto STCA extension is not truly about protecting the health and safety of Canadians. It is, instead, about the government's desire "to counter charges of not protecting the population from disease." ${ }^{161}$

155. ParlVU, "Meeting No. 16 Special Committee on the COVID-19 Pandemic" (3 Jun 2020) at 13h:57m, online (video): <parlvu.parl.gc.ca/Harmony/en/PowerBrowser/PowerBrowserV2/ 20200603/-1/33341? Language=English\&Stream=Video $>$ [perma.cc/8MT6-6X9G]; Hans Henri P Kluge et al, "Refugee and migrant health in the COVID-19 response" (2020) 395 The Lancet 1237 at 1238 .

156. Ali Tejpar \& Steven J Hoffman, "Canada's Violation of International Law during the 2014-2016 Ebola Outbreak” (2016) 54 Can YB Intl Law 366 at 371. See also Sharmila Devi, "Travel Restrictions Hampering COVID-19 Response" (2020) 395 The Lancet 1331.

157. World Health Organization, Handbook for public health capacity-building at ground crossings and cross-border collaboration, (2020) at 28, online (pdf): <apps.who.int/iris/bitstream/ handle/10665/331534/9789240000292-eng.pdf> [perma.cc/TQR5-JPH9].

158. Ibid.

159. Ibid. For a detailed discussion of the ways in which " $[\mathrm{m}]$ any of the travel restrictions being implemented during the COVID-19 outbreak are not supported by science or WHO," see Roojin Habibi et al, "Do not violate the International Health Regulations during the COVID-19 outbreak" (2020) 395 The Lancet 664.

160. UNHCR, COVID-19, supra note 131 at para 6.

161. Catherine Z Worsnop, "Domestic politics and the WHO's International Health Regulations: Explaining the use of trade and travel barriers during disease outbreaks" (2017) 12 Rev Intl Organizations 365 at 366 . 
Unfortunately, prominent members of the Conservative Party have levelled charges focused on the supposed risks posed by asylum-seekers. For example, Peter MacKay criticized the Prime Minister for "allowing illegal border crossings" when the country may not have "enough equipment for our own citizens."162 Similarly, Erin O'Toole, the newly elected leader of the Conservative Party, argued that "the resumption of illegal passage" would be "against the health of the Canadian public." 163 Travel restrictions are often implemented in response to this type of criticism "because they can quell public fear and instill confidence in the government." 164

To see that the de facto STCA extension is more about political signalling than public health, one needs only to consider what travel has (and has not) been deemed "essential" during the pandemic. For example, the Canadian government supported the National Hockey League's resumption of the 2019-2020 season in Canadian "hub cities." ${ }^{165}$ International travel by hockey players, coaches, and support staff has therefore been characterized as essential, while travelling to the country between POEs to seek asylum has not been. Similarly, it is unclear why it was deemed essential for Americans to travel to Alaska through Canada ${ }^{166}$ while travelling to Canada to attend the birth of one's child was not. ${ }^{167}$ Many of

162. Emerald Bensadoun, "Coronavirus: Asylum seekers irregularly crossing to Canada will be screened," Global News (17 March 2020), online: <globalnews.ca/news/6689836/ asylum-seekers-canada-coronavirus> [perma.cc/RQJ6-XG9A].

163. COVID-19 Committee, Meeting 2, supra note 150 at 13h:28m; Alex Boutilier, "Erin O'Toole wins Conservative Party leadership in major upset," Toronto Star (23 August 2020), online: <www.thestar.com/politics/federal/2020/08/23/conservative-party-leadership-racelive-coverage.html> [perma.cc/U3BN-VBZX].

164. Worsnop, supra note 161 at 366.

165. Canadian Press, "Federal Government clears path for NHL to have hub city in Canada: report" CBC Sports (18 June 2020), online: <www.cbc.ca/sports/hockey/nhl/ nhl-federal-government-canada-hub-city-1.5618558> [perma.cc/LK5G-6JC4]. See also Sean Rehaag, "Whose travel is 'essential' during coronavirus: Hockey players or asylum-seekers?" (17 June 2020), online: The Conversation <theconversation.com/whose-travel-is-essentialduring-coronavirus-hockey-players-or-asylum-seekers-140239> [perma.cc/NF44-DK2W].

166. Joel Dryden, "Banff residents worry U.S. tourists visiting town thanks to so-called 'Alaska loophole," CBC News (12 June 2020), online: <www.cbc.ca/news/canada/calgary/ banff-tourists-alaska-nina-stewart-michael-buxton-carr-1.5610417> [perma.cc/JV9E-P7CD].

167. See e.g. Janice Dickson, "U.S. man told travelling to Canada to attend son's birth is non-essential, denied border crossing," The Globe and Mail (15 May 2020), online: <www. theglobeandmail.com/politics/article-us-man-told-travelling-to-canada-to-attend-sons-birthis-non> [perma.cc/QP2S-HRGB]. 
these decisions have been largely left up to border officials, ${ }^{168}$ and they have often appeared quite arbitrary. ${ }^{169}$

Even less clear are the distinctions being made between asylum-seekers. Why are asylum seekers who enter Canada between official POEs considered a public health risk while STCA exempt asylum seekers who enter at official POEs are not? Without explanations for such distinctions, the Canadian government cannot reasonably argue that the present public health crisis requires them to direct asylum seekers entering between official POEs back to the US.

\section{COULD THE MEASURES RESULT IN REFOULEMENT?}

The question of whether returning asylum seekers to the US violates Canada's non-refoulement obligation was central to the applicants' arguments in CCR $v$ Canada. They argued that Canada is required to "not only prevent an asylum seeker's return to danger" but also to "take affirmative measures to prevent a risk of harm" by adopting measures that will "not result in [the asylum-seekers'] removal, directly or indirectly, to a place where their lives or freedom would be

168. See Immigration, Refugees and Citizenship Canada, "Travel restriction measures: COVID-19 program delivery" (last updated 12 June 2020), online: <www. canada.ca/en/immigration-refugees-citizenship/corporate/publications-manuals/ operational-bulletins-manuals/service-delivery/coronavirus/travel-restrictions.html\#purpose> [perma.cc/M95P-2QEG].

169. See e.g. Brigitte Bureau, "Internal documents show CBSA scenarios to decide who gets across the border-and who doesn't," CBC News (2 June 2020), online: <www.cbc.ca/news/ canada/ottawa/cbsa-document-outlines-scenarios-who-crosses-border-1.5594684> [perma. cc/LF2Q-BRL6]. The lack of clear guidance to the CBSA about who is considered "essential" has been a frequent source of conversation in the meetings of the Special Committee on the COVID-19 pandemic. For example, Elizabeth May called it "unacceptable" that CBSA agents "are exercising personal subjective judgment." See ParlVU, "Meeting No. 12 Special Committee on the COVID-19 Pandemic" (27 May 2020) at 13h:36m, online: <parlvu.parl.gc.ca/Harmony/en/PowerBrowser/PowerBrowserV2/20200527/-1/33322? Language $=$ English $\&$ Stream $=$ Video $>$ [perma.cc/2CUA-DRVV]. Similarly, Marilyn Gladu has highlighted "a number of inconsistencies in what is considered essential travel on the U.S. and in the interpretation of different CBSA agents," while Paul Manly spoke of families stranded overseas with non-Canadian spouses "being forced to make an impossible decision between sheltering in place overseas or separating from their spouse in order to return home." See ParlVU, "Meeting No. 3 Special Committee on the COVID-19 Pandemic (5 May 2020) at 12h:41m, online: <parlvu.parl.gc.ca/Harmony/ en/PowerBrowser/PowerBrowserV2/20200505/-1/33132?Language=English\&Stream= Video> [perma.cc/7CJ2-Q3MZ]; ParlVU, "Meeting No. 7 Special Committee on the COVID-19 Pandemic" (13 May 2020) at 14h:05m, online: <parlvu.parl.gc.ca/Harmony/en/ PowerBrowser/PowerBrowserV2/20200513/-1/33219?Language=English\&Stream=Video > [perma.cc/2YUD-SC4U]. 
in danger." ${ }^{170}$ The Federal Court did not rule directly on whether affirmative measures are required to avoid "chain refoulement." ${ }^{171}$ However, the court did find that the "sharing of responsibility' objective of the STCA should entail some guarantee of access to a fair refugee process," that such safeguards were "largely out of reach and ... therefore "illusory" and that, in the case of Ms. Mustefa, there was a "real and not speculative" risk of refoulement due to the applicant's detention in the US and "the challenges in advancing an asylum claim for those detained." 172

The current emergency direct-back policy appears to provide even fewer guarantees that a claimant will have access to a fair refugee process. In our view, a consideration of American deportation practices since the global pandemic began requires Canadian officials to halt direct backs. The Department of Homeland Security website states explicitly that if CBP cannot return "illegal immigrants" to Canada or Mexico, they "will return these aliens to their country of origin." 173 In addition to evidence that the US has further breached its obligations under international law at its southern border during the pandemic, ${ }^{174}$ evidence has emerged that the American government "has aggressively begun to rush the deportations of some of the most vulnerable migrant children in its care."175 This is in addition to a presidential memo dictating that any country refusing to accept deportees may be penalized with visa sanctions. ${ }^{176}$

170. CCR v Canada, Applicant's Memo, supra note 58 at para 59.

171. Chain refoulement has been described as "the removal of a refugee ... indirectly through a third country." See John Doe et al v Canada (2005), Inter-Am Comm HR, No 78/11 Annual Report of the Inter-American Commission on Human Rights: 2011, OEA/Ser.L/V/II. Doc 69 at para 103.

172. CCR v Canada, 2020, supra note 11 at paras 128, 130, 106.

173. DHS, supra note 126.

174. US Senator Patrick Leahy of Vermont, Press Release, "Leahy Leads Judiciary Committee Democrats in Demanding Answers About DHS' Newly Claimed Authorities to Override Federal Laws at Southern Border" (7 April 2020), online: <www.leahy.senate.gov/press/ leahy-leads-judiciary-committee-democrats-in-demanding-answers_about-dhs-newlyclaimed-authorities-to-override-federal-laws-at-southern-border> [perma.cc/8WS2-6ERY]; Michael Garcia Bochenek, "Trump Administration Uses Pandemic as Excuse to Expel Migrants” (20 May 2020), online: Human Rights Watch <www.hrw.org/news/2020/05/21/ trump-administration-uses-pandemic-excuse-expel-migrants> [perma.cc/45P6-PYX6].

175. Lomi Kriel, "The Trump Administration Is Rushing Deportations of Migrant Children During Coronavirus” (18 May 2020), online: Propublica <www.propublica.org/article/ the-trump-administration-is-rushing-deportations-of-migrant-children-during-coronavirus> [perma.cc/ELN8-Q6SG].

176. United States, Presidential Memoranda, Memorandum on Visa Sanctions (2020), online: <www.whitehouse.gov/presidential-actions/memorandum-visa-sanctions> [perma.cc/6RLR-NN8M]. 
These practices disregard the UNHCR's warnings against restrictions on access to asylum which "may contribute to the further spread" of COVID-19. ${ }^{177}$ There are numerous reports of deportees from the US being returned to their countries of origin despite testing positive for COVID-19, ${ }^{178}$ contributing to the rise of cases in those countries. ${ }^{179}$ This is especially concerning in light of reports about COVID-19 circulating in US detention facilities. ${ }^{180}$

None of this evidence was before the Federal Court in CCR $v$ Canada. In our view, it demonstrates that US refugee protection failures have only been exacerbated in the past several months.

Canadian officials have indicated that they have discussed these issues with their American counterparts. However, other than indicating that refugee issues are "very important" to Canada, they have not provided any details about what kind of assurances they have received from the US. ${ }^{181}$ They have, however, repeatedly affirmed that "asylum seekers who try to take the Roxham path are re-directed to the U.S." ${ }^{182}$ Canadian officials appear far more concerned with assuring critics that asylum-seekers are being kept out of the country than they are with ensuring that Canada is not complicit in chain refoulement.

177. UNHCR, COVID-19, supra note 131 at para 9.

178. See e.g. Arshad Mohammed, Julia Symmes Cobb \& Frank Jack Daniel, "Two dozen people deported to Colombia on U.S. flight found to have coronavirus: sources," Reuters (29 April 2020), online: <www.reuters.com/article/us-health-coronavirus-usa-colombia/ two-dozen-people-deported-to-colombia-on-u-s-flight-found-to-have-coronavirussources-idUSKBN22B3DB> [perma.cc/8QHP-669S]; Isabel Macdonald, "US to deport Haitians who've tested positive for coronavirus: NGO” (10 May 2020), online: Al Jazeera <www.aljazeera.com/news/2020/05/deport-haitians-tested-positivecoronavirus-ngo-200510202833575.html> [perma.cc/B8JW-EWNG].

179. Jonathan Blitzer, "The Trump Administration's Deportation Policy is Spreading the Coronavirus," The New Yorker (13 May 2020), online: <www.newyorker.com/news/dailycomment/the-trump-administrations-deportation-policy-is-spreading-the-coronavirus> [perma.cc/CJ7X-A6QD].

180. See supra note 128 and accompanying text.

181. Canadian Public Affairs Channel, "Federal ministers and Health Officials Provide COVID-19 Update" (26 March 2020) at 13m:58s, online (video): <cpac.ca/en/programs/ covid-19-canada-responds/episodes/66177165> [perma.cc/5YJN-6FG5].

182. Canadian Public Affairs Channel, "Federal Ministers and Health Officials Provide COVID-19 Update" (22 April 2020) at 17m:37s, online (video): <www.cpac.ca/en/ programs/covid-19-canada-responds/episodes/66189572> [perma.cc/454D-SGPE]. 


\section{ARE THE MEASURES TAKEN NON-DISCRIMINATORY?}

Finally, the UNHCR has emphasized that all measures implemented to manage risks to public health must be non-discriminatory. ${ }^{183}$ Similarly, the ICCPR requires that measures taken "not involve discrimination solely on the ground of ... sex." ${ }^{184}$ However, the government's actions extend the application of a policy which, according to the applicants in CCR $v$ Canada, contravenes the guarantees to equal protection and equal benefit of the law without discrimination under section 15 of the Charter. ${ }^{185}$

Although the Federal Court declined to address these arguments because of its other findings about how the STCA violates the Charter, the Court heard extensive evidence about how the STCA results "in a discriminatory distinction on the basis of sex" because female asylum seekers face barriers in accessing protection in the US. ${ }^{186}$ For example, the applicants in CCR $v$ Canada highlighted the "disproportionate effect on women of the one-year bar," 187 which is an American policy requiring asylum-seekers to "make their claim within one year of arrival in the U.S. to be eligible for asylum." 188 The applicants presented evidence that women miss this deadline "at a rate 13 per cent higher than men" because they are "often more reluctant to disclose their experiences to anyone-let alone government officials—-due to trauma, shame, and cultural norms tolerating gender-based persecution or that make discussing it taboo." 189

The applicants also highlighted barriers faced by women fleeing gender-based persecution (GBP) "due to a restrictive interpretation of key aspects of the refugee definition." ${ }^{190}$ It is well-established in Canadian refugee law that "although gender is not one of the grounds specified in the Refugee Convention, the Convention can be interpreted to grant protection to women who establish a well-founded fear of gender-based persecution" on account of their membership in a particular social group. ${ }^{191}$ By contrast, the applicants highlighted several ways in which "the US interpretation of the refugee definition excludes protection for women fleeing

183. UNHCR, COVID-19, supra note 131 at paras 5-7.

184. Mosher, supra note 116 at 930-31.

185. CCR v Canada, 2020, supra note 11 at paras 151-153.

186. CCR v Canada, Applicant's Memo, supra note 58 at para 93.

187. Ibid at para 95 .

188. Ibid at para 32 .

189. Ibid at para 35.

190. Ibid at para 95.

191. Sonia Akibo-Betts, "The Canada-U.S. Safe Third Country Agreement: Reinforcing Refugee Protection or putting Refugees at Risk" (2006) 6 J Institute Justice \& Intl Studies 1 at 6. See also Canada (Attorney General) v Ward, [1993] 2 SCR 689. 
GBP by private actors." ${ }^{192}$ They explained that by issuing a precedential decision in the Matter of $A-B$-, the American Attorney General established that "claims by aliens pertaining to domestic violence ... will not qualify for asylum." ${ }^{193}$ The applicants argued that the Matter of $A-B$ - makes it "nearly impossible" for asylum seekers fleeing GBP to receive asylum in the US. ${ }^{194}$

We agree with the applicants' assessment. In addition, we note that the situation facing female asylum seekers in the US has been threatened further since closing arguments in CCR $v$ Canada were heard. The Trump administration recently proposed amendments which would further prohibit the Secretary of Homeland Security from "favorably adjudicat[ing]" refugee claims founded on GBP. ${ }^{195}$

These policies differ dramatically from Canadian refugee law practice. Many have highlighted "Canada's international reputation for its recognition of" GBP claims and have argued that asylum seekers fleeing GBP have good reason to seek asylum in Canada rather than the US. ${ }^{196}$ In our view, the de facto extension of the STCA amplifies the discriminatory effect which the applicants detailed in their submissions.

In light of the significant concerns raised in CCR $v$ Canada, we were surprised to learn that " $[\mathrm{n}]$ o gender-based analysis plus $(\mathrm{GBA}+)$ impacts" were identified in the government's consideration of the IRPR changes outlined above. ${ }^{197}$ We would be interested to know how this conclusion was reached, and feel that a more thorough GBA+ is warranted. ${ }^{198}$

192. CCR v Canada, Applicant's Memo, supra note 58 at para 38.

193. Ibid at para 38. For a detailed discussion of this policy, see Holliday, supra note 50.

194. CCR v Canada, Applicant's Memo, supra note 58 at paras 40, 95.

195. Homeland Security Department and the Executive Office for Immigration Review, "Procedures for Asylum and Withholding of Removal; Fear and Reasonable Fear Review" (15 June 2020), online: Federal Register <www.federalregister.gov/documents/ 2020/06/15/2020-12575/procedures-for-asylum-and-withholding-of-removal-credible-fearand-reasonable-fear-review> [perma.cc/HTM9-BN4X].

196. Sonia Akibo-Betts, "The Canada-U.S. Safe Third Country Agreement: Why the U.S. Is Not a Safe Haven for Refugee Women Asserting Gender-Based Asylum Claims" (2005) 19 Windsor Rev Legal Soc Issues 105; Ibid at 111; Carasco, supra note 30 at 326-27.

197. CCR v Canada, Applicant's Memo, supra note 58 at para 93; Canada Gazette, 2020, supra note 103 at 558. For a discussion of GBA+ processes, see Status of Women Canada, "What is GBA+ (Gender-based Analysis Plus)" (4 December 2018), online: <cfc-swc.gc.ca/gba-acs/ index-en.html>.

198. If it is found that no GBA+ impacts exist, government officials must "demonstrate why there aren't any gendered dimensions." See Francesca Scala \& Stephanie Paterson, "Gendering Public Policy or Rationalizing Gender? Strategic Interventions and GBA+ Practice in Canada" (2017) 50 Can J of Political Science 427 at 437. 


\section{CONCLUSION}

The Canadian government's decision to implement the de facto STCA extension in the name of public health was not, as is required by the ICCPR, "the least restrictive of the options available" to the government to combat the spread of COVID-19. ${ }^{199}$ Further, the Canadian government was not in a situation where they had "no reasonable alternatives to prevent the introduction or spread of" COVID-19.200

Canada had many other reasonable policy alternatives available, such as including all asylum seekers amongst those travellers "with a worthy purpose" who are entitled to enter the country despite border closures, as Denmark has. ${ }^{201}$ Various screening and quarantine measures could also have been pursued. Instead, Canada chose emergency measures which violate obligations towards asylum-seekers under international law.

We believe that the Canadian government should take steps to rectify these errors and to ensure that the human rights of asylum seekers are respected. At a minimum, Canada should immediately stop using the pandemic as a pretext for further closing the border to refugees. ${ }^{202}$ Not only has the STCA itself been held to be unconstitutional, but no convincing public health justification has been advanced for extending it even further. The de facto extension of the STCA appears to be nothing more than a cynical attempt to leverage a crisis to make a political problem go away. The direct backs should end, and it should be made

199. Mosher, supra note 116 at 932.

200. Quarantine Act, supra note 99, s 58(d).

201. European Council on Refugees and Exiles, "Information Sheet 28 May 2020: COVID-19 Measures Related to Asylum and Migration Across Europe" (28 May 2020) at 3, online: <www.ecre.org/wp-content/uploads/2020/05/COVID-INFO-28-May.pdf> [perma. cc/5KPR-UCZJ] [ECRE]; International Organization of Migration, Issue Brief, COVID-19 Identification and Monitoring of Emerging Immigration, Consular and Visa Needs (IOM, April 2020) at 2, online (pdf): <www.iom.int/sites/default/files/our_work/ DMM/IBM/2020/en/covid-19iomissuebrief-immigrationconsularandvisarecommen dations.pdf> [perma.cc/V89Z-2RSJ]. For details on the Portuguese response, see Mia Alberti \& Vasco Cotovio, "Portugal give migrants and asylum-seekers full citizenship rights during coronavirus outbreak," CNN (31 March 2020), online: <edition.cnn. com/2020/03/30/europe/portugal-migrants-citizenship-rights-coronavirus-intl/index.html> [perma.cc/N9NG-NKBD].

202. We use the term "further" to recognize that the Canadian government has been involved in closing the border to refugees in various ways for many years. See e.g. Scott D Watson, The Securitization of Humanitarian Migration: Digging Moats and Sinking Boats (Taylor \& Francis Group, 2009) at 121-30; Macklin, 2005, supra note 16 at 378-80. 
clear that asylum seekers cannot be penalized for entering the country between POEs, as is their right under international law.

Better yet, Canada should demonstrate leadership by insisting that crossing the border to seek asylum is amongst the most essential forms of international travel. This leadership is necessary now more than ever. Refugees around the world face heightened risks as many states limit their ability to travel to seek asylum in response to the global pandemic. ${ }^{203}$ Canada should be a champion for asylum seekers, not another country using the pandemic to erect further barriers to their movement.

This leadership can be shown by halting plans to appeal CCR $v$ Canada, by accepting the Federal Court's finding that the $S T C A$ is unconstitutional and by immediately suspending the STCA. The US has long been unsafe for at least some refugees. It has become dramatically less safe under Trump's leadership. American responses to the global pandemic have made things even worse.

The Canadian government has acknowledged that it can safely process refugee claims during a pandemic by processing STCA exempt asylum seekers without issue. As the Federal Court found, no "current justifiable purpose" is served by treating differently those refugee claimants who "have the benefit of the exemptions carved out in the STCA" and those who do not. ${ }^{204}$ If the STCA is suspended, asylum seekers who do not meet these exemptions could enter the country at official POEs through the same process that STCA exempt asylum seekers are currently safely following. They could be screened for the virus. They could be appropriately quarantined.

Until Canada makes these changes, asylum seekers caught crossing between official POEs will be directed back to a country where they face a serious risk of refoulement and other rights violations. This policy will only encourage asylum seekers to cross the border in places where they will not be detected and to move underground when they come to Canada, because incentives to engage with the state do "not exist where individuals enter clandestinely." ${ }^{05}$ As a result, asylum seekers will not be screened for COVID-19 or quarantined upon entry. These policies do not "protect Canadians," they endanger them.

203. UNHCR reports that at least ninety-nine countries that have fully or partially closed their borders are making no exceptions for asylum seekers at all. See United Nations, "Policy Brief: COVID-19 and People on the Move" (5 June 2020) at 19, online (pdf): $U N<w w w$. un.org/sites/un2.un.org/files/sg_policy_brief_on_people_on_the_move.pdf> [perma.cc/ C4GX-V8L9]; See generally ECRE, supra note 200.

204. CCR v Canada, 2020, supra note 11 at paras 147-48.

205. Macklin, 2005, supra note 16 at 423. 
In the wake of the SARS epidemic, Janet Mosher highlighted that pandemics can present "an opportunity for us to rethink" necessary legal frameworks. ${ }^{206}$ We urge the Canadian government to take this opportunity to suspend the STCA, to revoke its de facto extension and to rethink what travel is, truly, "essential." 